\title{
Middle leading and influence in two Australian schools
}

Educational Management

Administration \& Leadership $1-17$

(C) The Author(s) 2019

Article reuse guidelines:

sagepub.com/journals-permissions

DOI: 10.1 I77/I74I|143219880324

journals.sagepub.com/home/ema

(S)SAGE

\author{
Kylie Lipscombe ${ }^{\mathbb{D}}$, Sharon Tindall-Ford \\ and Peter Grootenboer
}

\begin{abstract}
Increasingly, educational systems are appreciating the importance of middle leaders leading educational improvement in schools. Schools depend on middle leaders to lead site-based educational development in areas including curriculum development, teacher professional learning and student learning improvement. Middle leaders are in a unique but complex position where they influence both executive leadership and teachers within the school organisation. Adopting case study methodology to investigate the practices and influence of middle leaders leading a school-based educational development project, three semi-structured interviews and artefacts from two middle leaders were collected over eight months. The theory of practice architectures afforded an examination of data to explain the conditions and arrangements enabling and constraining the middle leaders' practices of influence. The findings showed middle leaders' influence was dependent on executive leadership support, time, formal role descriptions and trusting relationship. Furthermore, the results reveal middle leaders can influence educational development at the school level through advocating for, collaborating with, and empowering colleagues to support teacher ownership of sitebased projects. Of interest, this study showed influence can be reciprocal, between middle leaders and colleagues, and between middle leaders and executive leadership.
\end{abstract}

\section{Keywords}

Middle leadership, practice theory, leadership influence, teacher collaboration, distributed leadership

\section{Introduction}

There is an increasing awareness that educational development needs to be fundamentally conceived at the school level (Kemmis et al., 2014). This has been acknowledged by many education systems in Australia and worldwide. In these systems, funds and resources are provided for localised curriculum and professional learning programmes. In Australia such initiatives include the Middle Years Literacy and Numeracy Support in Victoria and the New South Wales

\section{Corresponding author:}

Kylie Lipscombe, School of Education, Faculty of Social Sciences, University of Wollongong, Northfields Avenue, Wollongong, New South Wales 2533, Australia.

Email: klipscom@uow.edu.au 
Department of Education's Hub School project. There are three common features to many of these school-based initiatives: (1) school leaders are crucial to success; (2) middle leaders play a significant leadership role; and (3) initiatives are focused on changing teacher practice and improving student achievement. School leadership is generally described in research and literature as influencing school practices, particularly teaching and learning (Leithwood et al., 2010) and arguably is most successful when distributed (Bush, 2014; Spillane, 2006) across the school instead of inherent to one individual leader. Through this view, leadership is therefore not simply a principal role but instead captures the activities enacted by leaders as they interact with others around a common goal (Spillane et al., 2004). To this end, literature reveals that the success, or otherwise, of school-level educational development is not only reliant on principals but largely dependent on middle leaders and their capacity to influence those they work with in the pursuit of school improvement (Harris and Jones, 2010). Despite the growing interest in middle leaders' practices (Harris and Jones, 2017), the majority of middle leadership research focuses on professional learning, curriculum development and leadership development (Grootenboer, 2018). There is, however, increasing interest in how middle leaders actually promote change within their school site (Fitzgerald and Gunter, 2006; Harris and Jones, 2010; Somech and Nammneh, 2019).

The purpose of this article is to examine, using the practice of theory architecture (Kemmis et al., 2014), the practices of influence of two middle leaders in two schools in Australia as they lead change through a school-based educational development project. To explore these practices, two central questions are posed: what practices of influence are enacted by middle leaders when leading change; and what conditions and arrangements enabled and constrained the middle leaders' capacity to influence? To address these questions, this article begins with a discussion on relevant research and literature and the conceptual and theoretical frameworks used to investigate middle leading practices and influence. This is followed by details of the study, findings and implications from the research.

\section{Background literature}

\section{Middle leading}

The term 'middle leader' has been used in a variety of ways in education (e.g. those who work between schools and government bureaucrats) (Hargreaves and Ainscow, 2015), but here we focus on those who work in schools. While it is commonly understood and appreciated that the leadership of principals is crucial in the provision of effective education, they are usually positioned too far away from the classroom to have much impact on day-to-day teaching and learning (Lingard et al., 2003). Middle leaders (e.g. heads of department, curriculum leaders) are central to schoolbased educational development, being ideally placed in the classroom with an acknowledged leadership role (Grootenboer, 2018).

Middle leading practices unfold in fundamentally different ways to those of principals. Positionally, they work with colleagues and, because they have dual roles of leader and teacher, they have to negotiate different demands, tasks and relationships (Grootenboer et al., 2014). For example, when leading a school-based initiative, a middle leader will often be the instigator, driver and facilitator, but as a teacher they will also engage as a co-learner and participant. Thus, the professional and curriculum development in the school applies to them as much as it does to others. Such positionality has certain challenges when leading school-based educational development. Gurr and Drysdale (2013), in their review of middle 
leading, discuss the challenges associated with lack of principal support and inexperience in leadership development. Leithwood (2016) identifies challenges associated with role clarity and expectations and the middle leader's own leadership understanding. One of the common issues reported by middle leaders is the responsibilities associated with their positionality within the school requiring them to work 'up' with executive leadership while at the same time work 'across and down' with teaching colleagues (Bassett, 2016). Of course, this position has affordances, such as allowing the middle leader to empathise with and understand the development from within, but it also has constraints, as their attention is divided between their teaching and leading roles (Grootenboer et al., 2017).

\section{Middle leading and influence}

Allied to our focus on middle leading is influence. While there is no clear consensus, generally leadership influence is related to power, where a leader's level of authority often determines how they persuade followers (Jarvis, 2012) to achieve a common goal. While successful principals positively influence their school (Leithwood et al., 2019; Louis et al., 2010), they cannot be the sole purview of teaching and learning (Renihan et al., 2006) as their work is often situated too far from the classroom. As a result, a more distributed leadership practice - where middle leaders are depended on to use their expertise in teaching and learning to influence student outcomes, curriculum and professional learning - is becoming more apparent (Grootenboer, 2018). Leithwood (2016) notes the critical influence that middle leading practices can have, explaining that distributing leading practice to the middle is likely to have greater influence on students than practices carried out only at the school level.

A distributed leadership approach, where expertise and authority are distributed across practices in the school (Bush, 2014; Spillane, 2006), is an important but complex challenge for middle leaders as they influence others. Middle leaders are arguable highly experienced teachers but often have limited levels of power (Gurr and Drysdale, 2013; Leithwood, 2016) and as such find it difficult to influence their colleagues. Hammersley-Fletcher and Strain (2011) explain that if middle leaders are to lead, they require both the resources and authority to do so. Wise (2001) explains that middle leaders often work between conflicting expectations from their principal and teacher colleagues, leading to conflict and an inability to influence successfully with authority. Middle leaders therefore often shy away from influencing through performance and management (Thorpe-Bennett and Powell, 2014), thus influencing teachers in supportive and collaborative ways (Engle et al., 2017) becomes a middle leadership priority.

An approach to influence through support and collaboration is through professional learning communities (PLCs). PLCs provide teachers an extended, supported learning opportunity to work together, with the purpose of building teacher collaboration, leading to school improvement and improved student outcomes (DuFour, 2004). Harris and Jones (2010) assert that middle leading influence can stem from developing PLCs of teachers working collaboratively to take collective responsibility for student learning. Similarly, Fitzgerald and Gunter (2006) suggest collaborative and supportive relationships with teachers, where students are placed at the centre of their work, is central to middle leadership.

Another common approach by middle leaders is supporting teachers through informal influence, where leadership is circuitous instead of direct. Shaked and Schechter (2017) explain that middle leaders can influence indirectly if they have an awareness of broader and connected 
Educational Management Administration \& Leadership XX(X)

influences that are enacted at various levels of the schools. This may relieve the pressure of limited authority as they instead see their leading practices within a whole-school perspective.

The above examples illustrate the importance of relationships and collaboration to middle leadership influence. Edwards-Groves et al. (2016) provide a nuanced understanding of how middle leaders' collaborative relationships with colleagues are reliant on relational trust, a multi-layered construct central to influencing and securing change in teacher practice. Such a sphere of influence creates an opportunity for a more transactional and multidimensional approach to influence from the one described at the beginning of this section, where, instead of influence situated within a power construct, middle leaders can instead influence those they work with and vice versa through collaborative approaches and trusting relationships.

\section{Theoretical framework: The theory of practice architectures}

We argue that to understand middle leaders' leading and influence when implementing a schoolbased educational development project, it is crucial to understand their thinking, actions and relationships (i.e. practices) while at the same time understanding the school context, and the interaction between the two. We conceptualise the middle leaders' leading and influence as social practices that comprise characteristic sayings, doings, and relatings (Kemmis et al., 2014). The theory of practice architectures (Kemmis and Grootenboer, 2008) evolved as there was a renaissance of interest in understandings and conceptions of practice (Schatzki, 2001), and serves in this study as a theoretical and analytical framework for understanding the influencing practices of middle leaders in their two school sites. By employing this framework, we endeavour to understand the middle leaders' influencing practices, which include their forms of understanding (sayings), their modes of action (doings), and the ways they relate to others and the environment in which they work (relating), as they lead school-based educational development projects. Further, we explore what enabled and/or constrained these practices by examining the local conditions in which they operated (i.e. practice architectures). Practice architectures are the cultural-discursive, material-economic and social-political conditions and arrangements within particular school sites. Kemmis et al., (2014) describe these practice architectures as follows:

Cultural-discursive arrangements, in the medium of language, that make the sayings of the practice possible; together with

Material-economic arrangements, in the medium of physical space-time, that make the doings of the practice possible; together with

Social-political arrangements, in the medium of power, solidarity and agency, that make the relatings of the practice possible.

To illustrate, a school middle leader's practices will involve particular language - sayings (e.g. coaching), tasks - doings (e.g. meetings), and relationships - relatings (e.g. mentor-mentee). These are enabled and constrained by cultural-discursive arrangements (e.g. school policies for Head of Department), material-economic arrangements (e.g. budgets), and social-political arrangements (e.g. the relationship with the principal). Furthermore, there is a reciprocal relationship in which the practice architectures in a school site mediate middle leaders' influencing practices, and simultaneously shape and are shaped by middle leaders' practices (Kemmis et al., 2014). It is beyond the scope of this paper to do justice to this rich and detailed theory of practice but, in brief, the leading practices of middle leaders are enabled and constrained by the practice 
Table I. Participant information.

\begin{tabular}{|c|c|c|c|c|}
\hline $\begin{array}{l}\text { Middle } \\
\text { leader }\end{array}$ & School information & Teaching experience & $\begin{array}{l}\text { Leadership } \\
\text { responsibilities }\end{array}$ & $\begin{array}{l}\text { School-based educational } \\
\text { development project }\end{array}$ \\
\hline Josie & $\begin{array}{l}\text { - Coastal secondary } \\
\text { school } \\
\text { - Approx. } 1100 \\
\text { students }\end{array}$ & $\begin{array}{l}\text { - Six years' English \& } \\
\text { history secondary } \\
\text { teaching }\end{array}$ & $\begin{array}{l}\text { - Six months' experience } \\
\text { in formal middle } \\
\text { leadership role } \\
\text { - Year } 7 \text { Year Advisor } \\
\text { - Mentor of beginning } \\
\text { teachers }\end{array}$ & $\begin{array}{l}\text { School-based mentoring } \\
\text { program for beginning } \\
\text { teachers }\end{array}$ \\
\hline Sarah & $\begin{array}{l}\text { - Rural primary } \\
\text { school } \\
\text { - Approx. } 100 \\
\text { students }\end{array}$ & $\begin{array}{l}20 \text { years' primary } \\
\text { teaching }\end{array}$ & $\begin{array}{l}\text { - I0+ years' experience } \\
\text { in formal middle } \\
\text { leadership role } \\
\text { - Experience in relieving } \\
\text { Assistant Principal } \\
\text { - Leader of Teaching \& } \\
\text { Learning } \\
\text { - Leader of Infant team } \\
\text { (Kindergarten - Year 2) }\end{array}$ & $\begin{array}{l}\text { School-based peer } \\
\text { teacher observation } \\
\text { program }\end{array}$ \\
\hline
\end{tabular}

architectures that exist in any given site. Thus, in understanding middle leaders' influencing practices, it is critical to focus not only on the practices of the individuals involved, but also on the local conditions and arrangements that enable and constrain those practices.

\section{Study details}

\section{Background to the study}

Two middle leaders from two Australian schools - one primary and one secondary - participated in this study. Both middle leaders participated in a nine-month university-led leadership professional development programme that focused on leaders designing a contextualised mentoring programme for their school. The researchers were not involved in the school-based initiative, but instead investigated how middle leading practices of influence developed and were enacted in the schools.

\section{Participants}

Both middle leaders were full-time classroom teachers with an acknowledged role leading an educational development project in their respective schools. Information regarding the two middle leader participants and their school-based educational development projects is presented in Table 1.

\section{A descriptive overview of the empirical case studies}

A description of the two case studies is presented here to provide an important contextualised overview of the particular educational development projects led by the two middle leaders.

Josie led the design and implementation of a school-based mentoring programme for beginning teachers in her secondary school. There was no current formalised process in the school to support approximately 10 beginning teachers that were employed each year. The programme was designed 
and implemented over a six-month period with no additional time allocation for Josie or resources for implementation. The programme consisted of Josie working with beginning teachers once or twice a term. Josie designed workshops and delivered them after school to support the beginning teachers in focus areas such as teacher accreditation and behavior management.

Sarah led the design and implementation of a peer teacher observation programme at her primary school. Two teams of teachers, Infants (Kindergarten to Year 2) and Primary (Year 3 to Year 6), were released from class to work together twice a term to observe each other's teaching and provide feedback. While each teacher could identify a particular focus to be observed, there was an expectation that the focus would align to the school priority of formative assessment and student feedback. Sarah co-designed the programme with teaching colleagues and led the organisation and facilitation of the initiative.

\section{Data collection}

The data was collected over an eight-month period and included interviews with middle leaders and the collection of a range of artefacts. Three semi-structured interviews were conducted with each middle leader; the first was three months after completion of the university-led professional development programme. This interview was intended to ascertain the middle leaders' roles and their plans for leading educational development projects in their schools. The second and third interviews, conducted three months and then eight months respectively after the initial interview, explored the middle leaders' practices as the school-based educational development project unfolded. All the interviews were audio-recorded and transcribed. Artefacts associated with the school-based educational development project included action plans, reflection notes, professional learning plans and school-based staff survey data. All artefacts were de-identified to maintain confidentiality.

\section{Data analysis}

In examining the influencing practices of middle leaders, this study has two aims. The first was to identify the middle leading practices of the two middle leaders leading school-based educational development projects and the second was to consider how these practices were shaped by local cultural-discursive, material-economic and social-political conditions and arrangements of the school sites. Initially, the researchers read independently all transcripts and artefacts. This was followed by a collaborative discussion to identify emerging ideas and initial themes in the data (Gibbs, 2007). Following the initial analysis, the theory of practice architectures (Kemmis et. al., 2014) was used as an analytical frame to identify the specific practices (sayings, doings and relatings) and associated practice architectures (cultural-discursive, material-economic and social-political) in each school site. This revealed the middle leading influencing practices, and the conditions that both enabled and constrained these practices, through the middle leaders' own descriptions and artefacts. We acknowledge that the two cases are vastly different, and each has a number of localised conditions that prefigured the middle leading practices. Therefore, our intent is not to compare the two cases, but to use them as illustrative examples of the influencing practices middle leaders employ when leading school-based educational development projects. 


\section{Findings}

The data analysis revealed three themes related to the influencing practices of the two middle leaders as they led educational development in their schools: (1) influencing with authority; (2) influencing through staff empowerment; and, (3) influencing through collaboration. For each theme, the constituent practices, and the arrangements and conditions that enabled or constrained them, are discussed. While it is necessary to organise the themes separately to report the findings, we acknowledge that they are not independent but, rather, integrated and related.

\section{Influencing with authority}

Josie and Sarah were both in formal middle leadership positions in which, to some degree, there was a level of leadership authority. This authority was perceived as legitimate (or in some cases illegitimate) within the social structure of the school, and was reported to be used by the middle leaders to influence and progress educational development. In addition, the social-political arrangements and conditions (relational positioning, principal support and executive mentoring), and cultural-discursive resources (formal role descriptions), served as practice architectures that enabled and constrained the middle leaders' perceived influence through authority.

Sarah was an experienced leader, responsible for teaching and learning in the Infant department and for teacher accreditation. Sarah indicated in her first interview that this "experience-based" authority resulted in a level of credibility with colleagues:

I've been here for a long time too, so that helps; you have that bit of a reputation... I guess you'd say

I'm a bit of a valued member of staff and people do come and get advice.

Sarah reported that, as a middle leader, she intentionally influenced teachers as a colleague rather than as a formal leader. She explained her past leading practices were enacted with greater levels of power, where she "would lead from the front" by directing her colleagues on what to do, and as such this social-political arrangement illustrates a typical leader-follower relationship between leadership and staff. She realised, however, that influencing her colleagues to participate in this way meant she was "doing all the work", resulting in colleagues being disempowered, and at times "not on the same page". Instead, with the peer observation programme she was leading, she related with staff as a fellow learner and colleague:

We all took turns in who would lead each person's [coaching] but we did it as a joint effort and I loved that ... last time I'm trying to fill gaps and trying to come up with solutions; this time I'd really sit back and think about what the person was saying ... I think, now as well ... just being an active participant, somebody that knows the aims ... I'm there as an equal in many ways to them [teachers] I have been part of that process ... as a colleague and with the principal [he] is the sounding board...

This relationship, as colleague rather than formal leader, was also evident in peer observation notes Sarah shared after she observed a colleague. The notes showed that Sarah observed the teacher in a focus area set by the teacher and then collected factual information only (e.g. tallies of the number of times the teacher provided feedback to students). This was shared with the teacher after the lesson as data and followed up with reflective questions, for example, 'What aspects were positive and effective for you today?' This transaction evidences that peer observations remain the 
responsibility of the teacher, not Sarah, and that Sarah's role was focussed on being data collector and facilitator, rather than evaluator.

In contrast to her relationships with her fellow teachers, Sarah reported that she used her formal authority as middle leader more directly with the principal when advocating for support for colleagues. She did this by requesting and securing material-economic resources through the principal to provide additional time release for teachers to engage in peer observations, and by securing a formal time slot for staff professional learning in the school meeting schedule. These examples illustrate the social-political arrangements of the relational positioning of the middle leader as an advocate for staff and an influencer of the principal's leading practices. Through working collaboratively with colleagues, Sarah created shared modes of action and understandings that enabled her to advocate with understanding to the principal. Through her relating with the principal and her colleagues, Sarah had the agency and authority needed to develop and secure material-economic arrangements that supported practices of staff development.

Josie reported that her relational positioning as an experienced teacher supported her to influence the beginning teachers in her school. In her second interview, she shared how her own experiences as a teacher were useful for working with beginning teachers:

Oh my goodness - I'm actually at that point been teaching for six years ... I actually have things that I can offer other people

In this interview Josie further explained how, at times, her own beliefs and experiences in the school shaped what she worked on with the beginning teachers:

I want to make sure that we're really strong on things like behavior management and classroom management for our young teachers because it is a difficult school and they [beginning teachers] don't always necessarily feel confident enough to seek assistance

Further, a PowerPoint on behavior management Josie presented to beginning teachers included a range of strategies derived from personal experience and preference, for example, language choice and teacher style. This illustrates how her own teaching experiences and authority provided the cultural-discursive conditions that enabled her leading practices as a mentor to influence the beginning teachers' teaching practices. However, it was also clear that Josie understood her role as an influencer as she shared ideas and practices that had 'worked for her', but not necessarily as some form of 'best practice' to be copied.

Josie also shared that, while she was confident that she could positively influence beginning teachers, she did not have this same level of authority with experienced teacher colleagues indicating the different social-political arrangements that enabled and constrained the nature of her middle leading practices. For example, in her second interview, she shared that she found it difficult to influence her colleagues to join her as a mentor for beginning teachers. It appears the absence of the formal role descriptions, which are typically used to legitimise discourses of power and make status explicit and official, shaped how experienced teachers related to Josie as a middle leader, and this in turn shaped her practices and her perceptions of what she could achieve. This led her to question her level of authority and ability to persuade experienced teacher colleagues to become mentors for beginning teachers: 
Because it's not a position where, for yourself, it's clearly identified and it's not a position where those, not below you, but those you're working with, always identify what your role is or what the benefit of your role is, whether it be to them or to their colleagues and you're also then not a part of that higher hierarchy. So, you're kind of stuck in this middle area which can be very frustrating.

Josie's uncertainty regarding her influence as a middle leader was further evidenced in her interactions with executive leadership. She explained that the beginning teacher mentoring initiative was included in the school plan without her knowledge. While she saw the inclusion of the programme in the school document as a positive in that the project was recognised and provided with supportive cultural-discursive conditions, she said that she would have liked to contribute to the plan, but felt she had limited capacity to influence school executive, explaining "It's not as strong as I would like but that's not yet my role within the school to be able to say, I think this". The social-political arrangements relating to her role in the school leadership hierarchy meant that Josie felt that her authority as middle leader was limited, and consequently her influence more broadly across the school organisation was constrained. In other words, the practice architectures in her school site meant that Josie's leading practices were enabled with the beginning teachers, but more constrained with experienced teacher colleagues and the school executive.

Part of the social-political arrangements that Josie reported she used to influence 'up' (i.e. leading practices) was the influence of her own informal mentor who was a member of the executive team. Josie explained that, while executive mentoring was not a formalised process, and as such had no allocated time or structures, the deputy principal recognised that providing support for Josie may support the development of her leading practices.

I think if I didn't have someone like Michelle [her executive mentor] that I'm working with that would be very frustrating ... having to face an executive that I didn't know very well and being a classroom teacher stepping into that setting can be quite confronting so being able to team up with someone who was already part of the executive, who also supported me and had a belief in me, was then able to go and advocate and be the voice - that was really helpful.

With the mentoring program becoming more established, Josie's reliance on the social-political support of her own mentor became less significant, and she indicated feeling less constrained in her relationship with the executive leadership team:

I would probably now feel comfortable to go to executive and represent the programme myself - rather than having Michelle as the mouthpiece - actually go along and say, 'Right, this is my proposal, this is what I think that we should be doing' ... I could actually sustain this but to do that I need the time and the resourcing and I can back myself to go in and present that to them and ask for what is needed.

It is clear from this quotation that Josie's experience in leading the mentoring programme enabled her to increase her confidence and authority. Through the social-political arrangement of having an executive mentor and the material-economic attribute of leading a schoolbased educational development project for a sustained period of time, Josie developed the capacity to persuade the executive leadership to provide the resources needed to sustain and develop the project. 


\section{Influencing through staff empowerment}

Data analysis revealed that staff empowerment was commonly used as a mechanism to influence the direction of professional learning, teacher reflection and executive decision-making. Both Sarah and Josie adopted a collegial approach, giving their colleagues a voice and power within the decision-making process, and were deliberate in collecting information about teachers' experiences and opinions. This enabled them to provide colleagues with a voice, understand their colleagues' needs, and develop shared language and understandings with the aim of ultimately influencing their colleagues' experiences and practices. Cultural-discursive resources of staff surveys, material-economic arrangements of time, and social-political arrangements of trust and ownership shaped these practices.

The cultural-discursive resource of staff surveys provided Sarah and Josie the mechanism to influence and develop staff professional learning. A survey was developed by Sarah and distributed to staff as a means of engaging colleagues in a discourse to identify their professional learning needs vis-à-vis their peer observations. The tool included questions such as: 'How would you rate your ability to paraphrase during discussions with colleagues.' The aggregated data from the survey were then used to inform the school executive to create the school's professional learning plan. For Sarah's school, the data she collected from the survey indicated that her colleagues were not confident nor had the techniques to provide observational feedback to peers. This led Sarah to organise workshops that provided her colleagues with training in data collection, giving feedback and asking reflective questions. Josie also used staff surveys to support the design and focus of the professional learning of staff. She set up an online survey asking beginning teachers to describe their strengths, weaknesses and goals. This information was then used to inform targeted professional learning for these teachers and informed Josie of the next phase of the programme.

The cultural-discursive resource of engaging with teachers to facilitate professional learning through collegial discussions was also an enabler that Sarah used to influence teacher practice. Sarah's staff development plan showed that she used staff surveys to develop an agreed way of collecting data on teacher practice as part of the peer observation programme. This set up a process for whole-of-staff conversation on how to provide feedback to peers by collecting observable data, and enabled them to move away from tricky issues related to judgment and evaluation, leading to the development of a shared language and understanding about peer feedback. By investing in the collegial exchange of ideas, Sarah acknowledged the individual perceptions and voices of colleagues but aimed for collective understanding and agreement on an approach to peer observations. This process provided a shared understanding and language that enabled collegial professional learning to unfold, and mitigated the potentially damaging effects of peer evaluations and judgments.

Of course, having the will and intent as captured in the cultural-discursive arrangements noted above is one thing, but without the associated material-economic conditions (in this case the time needed to collect and analyse the data), as well as appropriate social-political arrangements related to trust and the ownership of information, little progress would have been possible. The issue of ownership was identified by Sarah who stated:

I spent a long time last time and I realised it was a mistake - collating all the data and trying to work out how to best pop it in and then at that staff meeting, I very much said, 'Well this is what we are doing.' I owned the conversation and, although it had contributions for everybody, I'm not doing that again... and it's probably not doing me and them any favours because they're not feeling quite that ownership of stuff as well. 
The quote above indicates that Sarah felt teachers required greater input in, and ownership of, the information collection and the analysis practices - she realised she did not need to be collecting all the information and solving all the problems for the teaching team. Sarah acknowledged that information itself can, through critically reflective dialogue, influence teachers' understandings and decision-making.

\section{Influencing through teacher collaboration}

Both middle leaders worked in collaboration with teachers and leadership (i.e. in the middle) as a strategy to lead and influence change within their educational development projects. Social-political arrangements of co-design, co-learning and principal support were reported as useful for Sarah to influence teacher practice. For Josie, having the support of an executive mentor in the design and presentation of a beginning teacher programme provided support, expertise and increased her perceived influence as a leader. She also reported that mentorship increased her credibility among the school executive. For both Sarah and Josie, the limited availability of the material-economic resource of time was a constraint, with executive resourcing in terms of timetabling and workload being cited as crucial for enabling middle leaders to effectively collaborate and, as a result, influence their colleagues' practices.

Sarah took the deliberate approach of encouraging teachers in her school to be actively and positively involved in the peer observation programme by working collaboratively with her colleagues. Data revealed that Sarah's consultative approach purposively engaged her colleagues, including her principal, in the design and implementation of the peer observation programme. One example of this was the professional learning artefacts that showed how Sarah planned to structure staff workshops to ensure full participation and collective decision-making. This included the principal working alongside staff in learning and decision-making, as opposed to leading from the front. Instead of presenting the peer observation programme to colleagues she related to colleagues by working alongside them, reading and discussing relevant research papers and discussing different teacher observation approaches. She then facilitated activities for all staff to identify the strengths and limitations of the different approaches for their school. This consultative approach led Sarah to co-design, with her colleagues and with the principal, a school-specific peer observation programme. Sarah posited that her approach of working alongside her colleagues ensured a less hierarchical approach, and this created a more positive working relationship with her teaching peers.

Not that I feel that there were any walls up, I really don't because that's just the relationship I have with these guys, I don't feel we had that but if there were, it's well and truly down now because they realise that we work together, I want them to give feedback to me, I want them to question me, I want to improve my practice with them...

During the second interview, Sarah said that the school's material-economic arrangements of time and space, as well as the social-political condition of principal support, helped her to work consultatively with her colleagues.

[professional learning] is a school priority ... it's playing with the timetable ... changing little practicalities, having resources and he [the principal] has put the funds into it, it is resourced. 
This collaborative approach was not without its constraints. The positionality of 'expert teacher' and formal middle leadership role required a deliberate and disciplined approach as Sarah worked alongside her staff instead of above them.

a big one for me was just that balancing the mentoring/coaching and making clear which hat I've got on - coach or mentor - at the start of the session and sticking to it and my need to focus less on being an expert and more on empowering my colleagues even when their ideas mightn't necessarily be as ... not as good as mine but, be different to where I'm going... So it's just releasing the inner control freak I think and saying, 'Go away, go away.'

This quotation highlights the social-political arrangement of positionality for the middle leader in teacher collaboration, and it shows how Sarah perceived that in this space, influence was more powerful when it was achieved by working collaboratively with her colleagues on their ideas rather than directing them based on her own views.

Josie wanted to develop a collaborative approach to mentoring beginning teachers, rather than lead the project herself. However, she was constrained by the school's material-economic arrangements under which adequate time and resources were not provided. In Josie's original action plan, the establishment of a mentoring team that met every three weeks with beginning teachers was identified as a key action in the mentoring program. This aim was partially constrained in reality by the limited time and financial resources allocated to the programme. She explained at interview that, as a result, she couldn't develop the programme from the presentation of workshops to collaborative team mentoring of beginning teachers.

I acknowledge that we do not have resources to give me extra time ... as well as paying for a casual every time.... and there is always the concern for second-year beginning teacher funding.

For both middle leaders, changing their schools' material-economic conditions, for example by providing funding and time to release teachers, was viewed as critical to facilitate collaboration with colleagues, something Josie said reported she was unable to influence.

\section{Discussion and implications}

Middle leaders are acknowledged contributors to the development, implementation and success of school-based change (Grootenboer, 2018; Lingard et al., 2003), but typically they have been found to lack both experience and training in leadership, confidence and influence (Bassett, 2016; Cardno and Bassett, 2015; Gurr and Drysdale, 2013). From the accounts of the two middle leaders in this study and the practices they enacted in their contexts, three common influencing themes were identified: authority, staff empowerment, and collaboration. None of these influences stands alone: rather, the middle leaders enacted their different leading practices in combination with and in response to the circumstances and conditions that shaped their influence. What was clear was school-based educational development was dependent on the middle leaders' own experiences and practices, and the site-based arrangements and conditions. These factors enabled and constrained different leading practices of influence.

There are two findings, that may appear obvious, about what middle leaders needed to effectively influence: firstly they needed professional credibility with colleagues (Kemmis et al., 2014); and second, they needed an explicit formal job description (Leithwood, 2016). To develop 
credibility, the school's social-political conditions needed to provide opportunities for the middle leader to be involved in and lead school initiatives over an extended period. Experience leading school initiatives increased the middle leaders' understandings of their school contexts, and supported the development of expertise in leading learning and the building of professional and relational trust with colleagues. Edwards-Groves et al., (2016) found that relational trust between middle leaders and colleagues was foundational to driving school change. For Josie, who had less experience as both a teacher and a leader, the resource of executive mentoring provided support and opportunities to garner important insights into and understandings of the workings of the school. Mentoring from a senior member of the school executive legitimised her position and agency, and provided opportunities to influence 'up' to the executive team.

Middle leader credibility and, as a result, authority, was validated through a more formalised distributed leadership role, where position descriptions were acknowledged, valued and understood by all within the school (Farchi and Tubin, 2018). This seemed particularly important for Josie, who was leading in a large secondary school with limited experience and had no formal role description. The lack of a role description shaped both her own perception of the influence she had, and how others perceived her authority.

Due to the relational positioning of middle leadership, middle leaders have the capacity to connect school-based educational development to the development of teacher agency (Kemmis et al., 2014). Because of their social-political status as teachers and colleagues, middle leaders have the ability to enact leading practices that foster a shared responsibility for intellectual cultures that are characterised by cultural-discursive arrangements that develop teacher agency (Lingard et al., 2003). In this study, teacher agency was realised by the middle leaders as they empower staff as a tool to influence. This ensured that each school's professional learning initiative was informed by teachers' beliefs and ideas. Because teachers played a role in the middle leaders' planning of the school-based projects, they had the power to advocate for relevant professional learning. In turn, the information they provided empowered the middle leaders by giving them evidence to influence the school executive. Input from teachers provided crucial insights into the school workforce that the executive needed for effective school planning. This was particularly significant for Sarah, who used this information to act as an advocate for her colleagues. As a result, she reported that she gained the legitimacy needed to influence both 'across' to colleagues and 'up' to the school executive. These examples illustrate ways middle leaders can avoid the issues some researchers have highlighted with distributed leadership where, for example, a middle leader's authority to influence is disguised in hierarchical control of where 'responsibility for completing tasks is passed down the school hierarchy' (Hall, Gunter and Bragg, 2012: 187).

As the school-based educational development projects were informed by teachers' opinions, shared language and understandings were developed. This created the cultural-discursive arrangements that facilitated teaching practice and professional learning. In this way, teacher opinions were a powerful tool for transforming school practices. However, the ever-present factor that shaped the schools' material-economic conditions was the difficulty of providing the time needed to collect and analyse evidence, and the time needed to work with staff to use this information effectively.

For the middle leaders, collaborating with colleagues was central to influencing practices and educational development. Co-designing a school educational development project with the school executive provided opportunities for them to influence executive school planning. In addition, co-learning with teachers provided opportunities to work with colleagues (Harris and Jones, 2010), share experiences, build rapport and trust, and share a common language and understanding 
(Edwards-Groves et al., 2016; Lipscombe et al., 2019). This multi-directional collaborative work placed the middle leaders in a position of influence with a wide range of school personnel (Grootenboer, 2018). However, for collaboration to change teacher practice, appropriate material-economic conditions related to time, space and resources are needed. This led to middle leaders placing an emphasis on their ability to persuade the executive to provide these conditions, and a pressure to deliver for colleagues.

\section{Conclusion}

The aim of this article was to examine the practices of influence and the local conditions and arrangements that impacted the practice of two middle leaders as they led change through a school-based educational development project. Findings indicate that executive leadership support and resourcing, time, formal role descriptions, and trusting relationship were crucial for middle leaders to influence change at the local level. The study showed that middle leaders can influence educational development at the school level and that practices that encourage collective responsibility for, and ownership of, site-based projects are valuable. Practices associated with authority and an ability to work in collaboration to empower staff helped middle leaders to influence purposeful action to develop solutions to local issues in local contexts. While not a specific practice, this study also illustrates that middle leaders' influence can be reciprocal between middle leaders and colleagues, and between middle leaders and executive leadership.

While this study sheds light on the influencing practices of middle leaders when implementing a school-based educational development project, caution needs to be taken regarding transferability and reliability of findings. School contextual factors are critical in determining middle leaders' influence and practices, hence transferability of findings should not to be assumed. Concerns may be raised about the reliability of the findings as the basis to understand middle leaders' influence and practices, due to study design, with only two middle leaders and data derived solely from them. Future research with increased number of middle leader participants and data from colleagues, executive leadership and students to triangulate findings may support or refute the findings from this study.

To conclude, middle leading is exercised in different ways and under different conditions to principal leadership, and is also exercised differently across various sites (Grootenboer, 2018). Understanding both the practices of influence, and the site arrangements that impact on influence, has implications for middle leaders leading site-based projects, and principals who rely on and support their work. To this end, the theory of practice architectures is a useful and important lens for examining and showing how particular cultural-discursive, material-economic, and social-political arrangements enable and constrain certain practices within a school site.

There is a need for further research into middle leading influencing practices as schools move towards school-based educational development. While data from this study contributes to the understanding of practices and arrangements of influence across two school sites, it does not include observation data, an important consideration for future practice-based research. Furthermore, while this study is based on data about how middle leaders' practices influenced teacher and principal practices, there was no attempt to collect student data, and nor was there a focus on understanding changes in student learning. Examining student data should be a central consideration of future research into leaders' influence on school initiatives. 


\section{Declaration of conflicting interests}

The author(s) declared no potential conflicts of interest with respect to the research, authorship, and/or publication of this article.

\section{Funding}

This research received no specific grant from any funding agency in the public, commercial, or not-for-profit sectors.

\section{ORCID iD}

Kylie Lipscombe (D) https://orcid.org/0000-0001-9433-7971

\section{References}

Bassett M (2016) The role of middle leaders in New Zealand secondary schools: Expectations and challenges. Waikato Journal of Education 21(1): 97-108.

Bush T (2014) Applying distributed leadership across contexts. Educational Management Administration \& Leadership, 42(5): 601-602.

Cardno C and Bassett M (2015) Multiple perspectives of leadership development for middle-level pedagogical leaders in New Zealand secondary schools. Journal of Educational Leadership, Policy and Practice 30(2): 30-38.

DuFour R (2004) What is a "Professional Learning Community"? Educational Leadership 61(8): 6-11.

Edwards-Groves C, Grootenboer P and Ronnerman K (2016) Facilitating a culture of relational trust in school-based action research: recognising the role of middle leaders. Educational Action Research 24(3): 369-386.

Engle RI, Lopez ER, Gormley KE, Chan JA, Charns MP and Lukas CV (2017) What role do middle leaders plan in implementation of innovative practices? Health Care Management Review 42(1): $14-27$.

Farchi T and Tubin D (2018) Middle leaders in successful and less successful schools. School Leadership \& Management 39: 372-390.

Fitzgerald T and Gunter H (2006) Leading learning: Middle leadership in schools in England and New Zealand. Management in Education 20(3): 6-8.

Gibbs GR (2007) Analysing Qualitative Data. London: Sage.

Grootenboer P (2018) The Practices of School Middle Leadership. Singapore: Springer.

Grootenboer P, Rönnerman K and Edwards-Groves C (2017) Leading from the middle: A praxisoriented practice. In: Grootenboer P, Edwards-Groves C and Choy S (eds) Practice Theory Perspectives on Pedagogy and Education: Praxis, Diversity and Contestation. Singapore: Springer, pp. 243-263.

Grootenboer P, Edwards-Groves C and Rönnerman K (2014) Leading practice development: Voices from the middle. Professional Development in Education 41(3): 508-525.

Gurr D and Drysdale L (2013) Middle level secondary school leaders: Potential, constraints and implications for leadership preparation and development. Journal of Educational Administration 51(1): 55-71.

Hammersley-Fletcher L and Strain M (2011) Power, agency and middle leadership in English primary schools. British Educational Research Journal 37(5): 871-884.

Hall D, Gunter H and Bragg J (2012) Leadership, New public management and the remodelling and regulation of teacher identities. International Journal of Leadership in Education 16(2): 173-190. 
Hargreaves A and Ainscow M (2015) The top and bottom of leadership and change. Phi Delta Kappan 97(3): 42-48.

Harris A and Jones M (2017) Leading in context: Putting international comparisons into perspective. School Leadership \& Management 37(5): 431-433.

Harris A and Jones M (2010). Professional learning communities and system improvement. Improving Schools 13(2): 172-181.

Jarvis A (2012) The necessity for collegiality: Power, authority and influence in the middle. Educational Management Administration \& Leadership 40(4): 480-493.

Kemmis S, Mctaggart R and Nixon R (2014) The Action Research Planner. Doing Critical Participatory Action Research. Singapore: Springer.

Kemmis S and Grootenboer P (2008) Situating praxis in practice. In: Smith SK and Smith T (eds) Enabling Praxis: Challenges for Education. Amsterdam: Sense Publishing, pp. 37-62.

Kemmis S, Wilkinson J, Edwards-Groves C, Hardy I, Grootenboer P and Bristol L (2014) Changing Practices, Changing Education. Singapore: Springer.

Leithwood K (2016) Department-head leadership for school improvement. Leadership and Policy in Schools 15(2): 117-140.

Leithwood K, Patten S and Jantzi D (2010) Testing a conception of how school leadership influences student learning. Educational Administration Quarterly 46(5): 671-706.

Leithwood K, Harris A and Hopkins D (2019) Seven strong claims about successful school leadership revisited. School Leadership \&, Management. DOI: 10.1080/13632434.2019.1596077.

Lingard B, Hayes D, Mills M and Chrisite P (2003) Leading Learning: Making Hope Practical in Schools. Maidenhead: Open University Press.

Lipscombe K, Buckley-Walker K and McNamara P (2019) Understanding collaborative teacher teams as open systems for professional development. Professional Development in Education. DOI: 10.1080/ 19415257.2019.1613256.

Louis KS, Leithwood K, Wahlstrom KL and Anderson SE (2010) Investigating the links to improved student learning: final report of research findings, University of Minnesota, University of Toronto, and Wallace Foundation. Available at: www.wallacefoundation.org (accessed 13 May 2018).

Renihan P, Phillips S and Raham H (2006) The Role of the School Principal: Present Status and Future Challenges in Managing Effective Schools. Kelowna, BC: Society for the Advancement of Excellence in Education.

Schatzki TR (2001) Introduction: Practice theory. In: Schatzki T, Knorr-Cetina K and von Savigny E (eds) The Practice Turn in Contemporary Social Theory. London: Routledge, pp. 10-21.

Shaked H and Schechter C (2017) Systems thinking among school middle leaders. Educational Management Administration \& Leadership 45(4): 699-718.

Somech A and Naamneh M (2019) Subject coordinators as boundary managers: The impact on team learning and organizational outcomes. Educational Management Administration \& Leadership 47(1): 56-73.

Spillane JP (2006) Distributed Leadership. San Francisco, CA: Jossey-Bass.

Spillane JP, Halverson R and Diamond JB (2004) Towards a theory of leadership practice: A distributed perspective. Journal of Curriculum Studies 36(1): 3-34.

Thorpe A and Bennett-Powell G (2014) The perceptions of secondary school middle leaders regarding their needs following a middle leadership development programme. Management in Education 28(2): $52-57$.

Wise C (2001) The monitoring role of the academic middle manager in secondary schools. Educational Management \& Administration 29(3): 333-341. 


\section{Author biographies}

Kylie Lipscombe currently coordinates educational leadership in the School of Education at the University of Wollongong. She has formally held roles such as teacher, deputy principal, curriculum consultant and lecturer. Kylie is passionate about the nexus between educational research and practice. As such, her program of research is aimed at positively influencing professional practice in schools in the fields of educational leadership and professional learning. This includes investigating middle leadership, teacher collaboration, and school and university collaborative partnerships. She is a keen contributor to and leader in professional education associations and is currently serving on the NSW Australian Council for Educational Leaders (ACEL) executive board.

Sharon Tindall-Ford is an associate professor at the University of Wollongong. Sharon's research has focused on making a positive change for school students, pre-service teachers, teachers and school leaders. Sharon has had over 30 years of experience in schools and university, her research has focused on two distinct areas - Cognitive Load Theory (CLT) and teacher learning. In CLT she has investigated instructional designs that support student learning. This work has informed the 2019 NSW Department of Education publication: 'Cognitive load theory: Research that teachers really need to understand'. Her most recent research has focused on three key inter-related areas: middle leadership, teacher policy (including teacher education), and pre-service and teacher learning. Sharon has led and contributed to research supported by university funding and from education organisations and has co-published 27 academic publications.

Peter Grootenboer was a school teacher and leader for 12 years before moving into the tertiary sector. He received a national Jim Campbell Award for teaching excellence. He is now a Professor in Education at Griffith University and the Director of the Griffith Institute for Educational Research. His recent books include: The Practices of School Middle Leadership (authored), and Changing Practices, Changing Education and Mathematics, Affect and Learning (co-authored). His research interests include practice/praxis theory, mathematics education, educational leadership, action research, and issues of educational social justice. 